\title{
KNOWLEDGE AND PRACTICE OF WOMEN REGARDING CERVICAL CANCER IN A PRIMARY HEALTH CARE UNIT
}

\author{
Maria Fernanda Leite ${ }^{1}$, Fabiana Cristina Frigieri De Vitta ${ }^{2}$, Letícia Carnaz ${ }^{3}$, \\ Marta Helena Souza De Conti ${ }^{3}$, Sara Nader Marta ${ }^{4}$, Márcia Aparecida Nuevo Gatti ${ }^{1}$, \\ Sandra Fiorelli de Almeida Penteado Simeão ${ }^{5}$, Alberto De Vitta ${ }^{3}$
}

\begin{abstract}
Objectives: evaluating the level of information about the examination of uterine cervical cancer and its association with sociodemographic variables in women of a health care unit in the city of Bauru, São Paulo, Brazil. Methods: we conducted a cross-sectional descriptive study with 370 women aged 25 to 59, through structured interviews in their own homes; we used descriptive statistics and the $\chi^{2}$ test. Results: $40.5 \%$ of the women had not undergone the Papanicolaou test at the recommended frequency; $58.2 \%$ incorrectly defined the test, and $69.5 \%$ did not know about the risk factors for the development of cervical cancer; the knowledge about the test showed statistically significant association with schooling and family income of the studied population. Conclusions: women present deficiencies on the proper practice of the Papanicolaou test, on knowledge about the test, risk factors and prevention methods. Therefore, it is necessary to develop primary health actions for the most vulnerable population.
\end{abstract}

Key words: knowledge, risk factors, uterine cervical neoplasms, vaginal wet mount, women's health.

\section{INTRODUCTION}

Cervical cancer is the second most frequent form of the disease among women, in Brazil, following non-melanoma skin cancer. Brazilian government, in the year 2011, expected 18,430 new cases, with an estimated risk of 18 cases for every 100 thousand women. In analyses of Brazilian regions, cervical cancer (CC) is the most common form of the disease in the North, with 23 cases for every 100 thousand women. It is the second most common form of cancer in the Midwest and Northeast regions, with rates of $20 / 100$ thousand and $18 / 100$ thousand, respectively, and the third in the Southwest (21/100 thousand) and South (16/100 thousand $)^{1,2}$.

The aetiology of CC is directly related to environmental factors, life habits and social factors, such as low socioeconomic conditions, which are highly related to risk factors related to CC: tobacco, inadequate intimate hygiene, early onset of sexual activity, multiple sexual partners, prolonged use of oral contraceptives and inadequate knowledge about the disease ${ }^{3,4,5}$.
In 1988, the Brazilian Ministry of Health adopted the World Health Organization (WHO) norms, which propose the control of CC for women aged between 25 and 60 , by performing the Papanicolaou test every three years, after two negative results in one year intervals. However, estimates indicate that about $40 \%$ to $57 \%$ of Brazilian women of all ages had never taken this control test. Some of the reasons for this are: difficulty accessing health services, the test nature - which involves the exposure of genitalia, and may cause emotional distress for some women -, as well as socioeconomic conditions and the lack of knowledge about gynaecological cancer ${ }^{6,7}$.

Thus, the high rates of mortality by CC and the effectiveness of the Papanicolaou test for the prevention of the disease justify the researches to assess the information level of women regarding $\mathrm{CC}$ and the relation between the disease's development and the sociodemographic variables. This knowledge may contribute to the participation

1 Professor of Nursing at the Health Sciences Centre of Universidade Sagrado Coração (USC), Rua Ir. Arminda, 10-50, Jd. Brasil, CEP: 17011-160; Bauru, SP, Brazil.

2 Professor at the College of Education of Universidade Estadual Paulita, Av. Hygino Muzzi Filho, 737, CEP 17525-900; Marília, SP, Brazil.

3 Professor of Physiotherapy at the Health Sciences Centre of Universidade Sagrado Coração (USC), Bauru, SP. Rua Ir. Arminda, 1050, Jd. Brasil, CEP: 17011-160; Bauru, SP, Brazil.

4 Professor of Odontology at the Health Sciences Centre of Universidade Sagrado Coração (USC), Rua Ir. Arminda, 10-50, Jd. Brasil, CEP: 17011-160; Bauru, SP, Brazil.

5 Professor of Mathematics at the Humanities Centre of Universidade Sagrado Coração (USC), Rua Ir. Arminda, 10-50, Jd. Brasil, CEP: 17011-160; Bauru, SP, Brazil.

Accomplished for the Postgraduate program in Public Health of Universidade Sagrado Coração (USC).

Corresponding author: albvitta@yahoo.com.br

Suggested citation: Leite MF, et al. Knowledge and practice of women regarding cervical cancer in a primary health care unit, Journal of Human Growth and Development, 24(2): 208-213

Manuscript submitted Oct 08 2013, accepted for publication Feb 222014. 
of people on decisions that affect their health and to support the health systems and improve the health status of individuals, families and communities ${ }^{8,9}$.

The objective is to evaluate the information level about cervical cancer examinations and its association with sociodemographic variables on women who attend primary health care units.

\section{METHODS}

This is a cross-sectional study, conducted with women aged from 25 to 59, registered at a Health Care Unit of a neighbourhood in the city of Bauru. This unit was chosen for being in a Primary Care operational region of Universidade Sagrado Coração (USC).

The city of Bauru (SP) is in the South East region of the state; it has an area of $702 \mathrm{~km}$, and it sits $324 \mathrm{~km}$ far from the capital. The 2010 Census stated that Bauru has 343,937 inhabitants; 177,288 of these are women and 89,848 are aged between 25 and $59^{10}$.

The neighbourhood houses a lower middle class young/adult population, a large number of housing complexes and access to treated water and sewer system. The place also has a primary health care unit to assist in various health specialities.

We obtained the health care unit's registry of all women between 25 and 59 years old: the sample size was calculated from the population of 5,178 registered women. For this analysis, we assumed the proportion of $20 \%$ of the population with the studied features ${ }^{11}$, an acceptable error of 4 percentage points, confidence level of $95 \%, 1.5$ design effect, with the addition of $15 \%$ for possible losses and refusals. The calculation defined a sample of 370 women. We then conducted the draw of participants through simple random sampling. A new participant was drawn whenever an individual chose not to take part in the research or could not be found after three visits.

Four undergraduate students performed the interviews and the researcher supervised them. The interviewers were trained based on a standardization protocol of data collection procedures (theoretical and practical) that were previously established, in order to minimize possible intra- and inter-evaluation errors. However, intraand inter-evaluation reliability was not determined. $10 \%$ of the sample was reassessed by the supervisor for quality control of data. The subjects were interviewed at home, in a six-month period. Interviews took on average 50 minutes each.

The selected women were informed about all the details regarding the research, including its objectives and the guarantee of confidentiality of the provided information; they were then asked whether they wanted to participate in the study or not. Those who voluntarily agreed signed the consent form and answered the questionnaire. This research was approved by the Research Ethics Committee of the Universidade Sagrado Coração.
People who could not answer the questionnaire (the mentally disabled individuals, the ones with neurological sequelae, the ones who were not found after three visits or who did not agree to participate in the study) were excluded from the survey.

The interviews were based on a structured questionnaire, aimed at finding socioeconomic and demographic characteristics (age, schooling, marital status) of women, as well as the factors related to development of CC, such as: 1) Number of pregnancies; 2) Number of living children; 3) Number of abortions (spontaneous or not); 4) Have you ever been through a Papanicolaou test? When was the last time you took the test?; 5) Do you know how the test is performed? How often should you do it?; 6) What is cervical cancer?; 7) What are the causes of cervical cancer?; 8) How to prevent cervical cancer?

The following definitions were adopted and used in a previous study ${ }^{12}$ to analyse data regarding the knowledge about Papanicolaou test:

- Adequate knowledge: Women who had heard about the test, and who knew it is used to detect general cancer or cervical cancer.

- Inadequate knowledge: Women who had never heard about the test, or who had heard about it, but did not know it is used to detect cervical cancer.

- Adequate practice: Women who took the Papanicolaou test in the last three years.

- Inadequate practice: Women who had taken the last Papanicolaou test more than three years before the interview, or only once in their lifetime.

Data collected was processed and analysed through EPI-Info (6.04 version) and Excel 1997 applications. We used resources of descriptive statistics and the $\chi^{2}$ test for the data analysis, with significance level of $5 \%$ to test differences between proportions $^{13}$

\section{RESULTS}

The study excluded $3.1 \%$ of women due to refusals and $5.6 \%$ did not participate because they were not found at home. $58.9 \%$ of the 370 interviewed women were less than 39 years old; $77.3 \%$ were married or in a stable relationship with a partner; $58.4 \%$ had less than six years of schooling; $51.9 \%$ had a family income of less than two times the minimum wage; and $86.2 \%$ had given birth to three children or less.

$59.5 \%$ of the interviewed women had taken the Papanicolaou test in the last three months before the interview and $40.5 \%$ had not taken it in the recommended frequency. These are some of the main reasons for not taking the test: $25.8 \%$ said they thought it was unnecessary; $25.2 \%$ referred 
Table 1: Distribution of women according to the studied characteristics. Bauru, Brazil, 2010. (N=370)

\begin{tabular}{|c|c|c|c|}
\hline & Characteristics & $\mathbf{N}$ & $\%$ \\
\hline Age & $\begin{array}{l}<39 \text { years old } \\
>40 \text { years old }\end{array}$ & $\begin{array}{l}218 \\
152\end{array}$ & $\begin{array}{l}58.9 \\
41.1\end{array}$ \\
\hline Schooling & $\begin{array}{l}<6 \text { years } \\
>7 \text { years }\end{array}$ & $\begin{array}{l}216 \\
154\end{array}$ & $\begin{array}{l}58.4 \\
41.6\end{array}$ \\
\hline Marital status & $\begin{array}{l}\text { Married/Stable } \\
\text { relationship } \\
\text { Others }\end{array}$ & $\begin{array}{l}286 \\
84\end{array}$ & $\begin{array}{l}77.3 \\
22.7\end{array}$ \\
\hline Family income & $\begin{array}{l}<2 \mathrm{MW} \\
>3 \mathrm{MW}\end{array}$ & $\begin{array}{l}192 \\
178\end{array}$ & $\begin{array}{l}51.9 \\
48.1\end{array}$ \\
\hline Childbirths & $\begin{array}{l}<3 \text { births } \\
>4 \text { births }\end{array}$ & $\begin{array}{c}319 \\
51\end{array}$ & $\begin{array}{l}86.2 \\
13.8\end{array}$ \\
\hline
\end{tabular}

$59.5 \%$ of the interviewed women had taken the Papanicolaou test in the last three months before the interview and $40.5 \%$ had not taken it in the recommended frequency. These are some of the main reasons for not taking the test: $25.8 \%$ said they thought it was unnecessary; $25.2 \%$ referred to service delays or the lack of doctors; $24.1 \%$ reported emotional discomfort (embarrassment) due to exposure of genitalia (Table 2).

Table 2: Appropriate practice of the Papanicolaou test and reasons for not taking the test, as mentioned by the interviewees. Bauru, Brazil, 2010. $(\mathrm{N}=370)$

\begin{tabular}{|c|c|c|c|}
\hline & Characteristics & $\mathbf{N}$ & $\%$ \\
\hline Adequate practice & Yes & 220 & 59.5 \\
\hline \multirow{4}{*}{$\begin{array}{l}\text { Reasons for not } \\
\text { taking the test* }\end{array}$} & $\begin{array}{l}\text { No } \\
\text { Thinks it is }\end{array}$ & $\begin{array}{c}150 \\
46\end{array}$ & $\begin{array}{l}40.5 \\
25.8\end{array}$ \\
\hline & $\begin{array}{l}\text { unnecessary } \\
\text { Service delays or } \\
\text { lack of doctors } \\
\text { Emotional discomfort }\end{array}$ & $\begin{array}{l}45 \\
43\end{array}$ & $\begin{array}{l}25.2 \\
24.1\end{array}$ \\
\hline & Not enough time & 18 & 10.1 \\
\hline & $\begin{array}{l}\text { Wrong information received } \\
\text { from health professionals }\end{array}$ & 16 & 8.9 \\
\hline
\end{tabular}

*Each woman could give more than one answer (sum $>100 \%$ )

As shown in Table 3, 58.2\% of the women incorrectly defined the test and $69.5 \%$ could not report what the risk factors are. When asked about how to prevent CC, $57 \%$ of them reported that the main form of prevention is the Papanicolaou test, and $35.4 \%$ did not answer the question.

Table 3: Adequate knowledge of the Papanicolaou test, risk factors and prevention forms of cervical cancer, as informed by the interviewees. Bauru, Brazil, 2010. $(\mathrm{N}=370)$

$\begin{array}{lccc} & \text { Characteristics } & \mathbf{N} & \% \\ \text { Adequate knowledge } & \text { Yes } & 155 & 41.8 \\ \text { Risk factors* } & \text { No } & 215 & 58.2 \\ & \text { Does not know } & 257 & 69.5 \\ & \text { Poor hygiene } & 59 & 9.5 \\ & \text { Endometriosis } & 35 & 7.5 \\ & \text { Sexually } & 28 & 5.0 \\ \text { transmitted } & \text { diseases } & 4.5 \\ \text { Prevention } & \text { Poor diet } & 19 & 35.4 \\ \text { methods* } & \text { Psychological } & 17 & 57.0 \\ & \text { problems } & 131 & 11.8\end{array}$

\footnotetext{
* Each woman could give more than one answer (sum $>100 \%$ )
} 
Knowledge about the test showed statistically significant association with some of the studied characteristics (Table 4). Significantly higher proportions of adequate knowledge were identified among women with schooling of 7 years or more and among those who reported a family income of three or more times the minimum wage. Higher percentages of adequate practice were observed among women aged 39 or less, with schooling equal to or higher than seven years, and among those who reported a family income of three or more times the minimum wage.

Table 4: Evaluation of adequate knowledge and practice regarding the Papanicolaou test, as informed by the interviewees. Bauru, Brazil, 2010. ( $N=370)$

\begin{tabular}{|c|c|c|c|c|c|}
\hline & \multirow[t]{2}{*}{ Characteristics } & \multicolumn{2}{|c|}{$\begin{array}{c}\text { Adequate } \\
\text { knowledge }\end{array}$} & \multicolumn{2}{|c|}{$\begin{array}{c}\text { Adequate } \\
\text { practice }\end{array}$} \\
\hline & & N (\%) & $\mathbf{p}$ & N (\%) & $\mathbf{p}$ \\
\hline Age group & $\begin{array}{l}>40 \text { years old } \\
<39 \text { years old }\end{array}$ & $\begin{array}{c}8(44.4) \\
10(55.6)\end{array}$ & NS & $\begin{array}{l}65(29.5) \\
155(70.5)\end{array}$ & $0 . \overline{0}$ \\
\hline Schooling & $\begin{array}{l}>7 \text { years } \\
<6 \text { years }\end{array}$ & $\begin{array}{l}12(66.7) \\
6(33.3)\end{array}$ & 0.03 & $\begin{array}{l}111(50.5) \\
109(49.5)\end{array}$ & 0.001 \\
\hline Marital status & $\begin{array}{c}\text { Married/Stable relationship } \\
\text { Others }\end{array}$ & $\begin{array}{l}13(72.2) \\
5(27.8)\end{array}$ & NS & $\begin{array}{l}169(76.8) \\
51(23.2)\end{array}$ & NS \\
\hline Family income & $\begin{array}{l}>2 \mathrm{MW} \\
<3 \mathrm{MW}\end{array}$ & $\begin{array}{c}5(27.8) \\
13(72.2)\end{array}$ & $0 . \overline{-}$ & $\begin{array}{l}103(46.8) \\
117(53.2)\end{array}$ & $0 . \overline{0} 05$ \\
\hline Childbirths & $\begin{array}{l}>3 \text { births } \\
<4 \text { births }\end{array}$ & $\begin{aligned} 17 & (94.4) \\
1 & (5.6)\end{aligned}$ & NS & $\begin{array}{l}196(89.1) \\
24(10.9)\end{array}$ & NS \\
\hline
\end{tabular}

MW: minimum wage

NS: not significant

\section{DISCUSSION}

Among the interviewed women, 59.5\% presented adequate practice regarding the Papanicolaou test in the last three years. The result is similar in the city of São Paulo, where previous studies identified adequate practice regarding the Papanicolaou test in $60.8-65.5 \%$ of the studied women ${ }^{14,15}$. However, these data from the South East region are lower than the results from the South region of Brazil, where the adequate practice is performed by $80 \%$ of the women (in the cities of Londrina and Guarapuava ${ }^{16,17}$ ). These differences probably occur due to the decentralization proposed by the Unified Health System: each city selects its own health strategies and actions, as the evaluated populations have similar sociodemographic characteristics. Yet, it is noteworthy that the rate of $59.5 \%$ of women in Bauru having adequate practices is considerably lower than the minimum rate of $80 \%$, which is recommended by the Pan American Health Organization (PAHO), to significantly reduce the mortality rates from cervical cancer.

We can also observe that $40.5 \%$ of women did not take the Papanicolaou test in the recommended frequency, and $13.5 \%$ of these had never taken it. This last figure is similar to what was found in the cities of São José do Mipibu $(\mathrm{RN})^{18}$, São Luiz (MA) $(17.6 \%)^{19}$, São Paulo $(13.9 \%)^{15}$, Campinas (SP) $(11.2 \%)^{20}$ and Guarapuava $(17 \%)^{16}$.

The main barriers for the appropriate procedures, from what the women think, are: they find it unnecessary; there is service delay or lack of doctors; there is emotional discomfort (embarrassment). These reasons were similar to what was seen in the cities of São José do Mipibu $(\mathrm{RN}, \mathrm{Brasil})^{18}$ and Umuarama (PR $)^{21}$, in which women argued there is carelessness, ignorance and lack of medical requests for the tests, as well as fear and embarrassment, as the main reasons to inadequate practice. Likewise, Argentine ${ }^{11}$ and Chilean ${ }^{22}$ women pointed out similar factors for not submitting to the Papanicolaou test: lack of medical request; ignorance; they do not feel sick or present symptoms; the embarrassment caused by the test, due to genitalia exposition. Therefore, it is possible to think about how difficult it is for these women to have access to the exams and to the other health services, and to change their knowledge and preventive habits. In another study, carried out with female workers of textile industries, we observed that more women took the Papanicolaou test and knew about its purpose; we may associate this fact to the possibilities offered by their job, which shows the importance of actions that link social and health sectors ${ }^{5}$.

It became evident from this research that $58.2 \%$ of women had no adequate knowledge about the Papanicolaou test. Similar data were reported by studies in Argentina $(50.5 \%)^{11}$, Peru $(52 \%)^{23}$ and in São José do Mipibu (RN, Brazil) $(53.9 \%)^{18}$.

Other important information from this study relates to the knowledge of women about risk factors and prevention forms of cervical cancer. $69.5 \%$ of all women in the study could not report what the risk factors for the development of cervical cancer are. Among the women from the city of Propriá (SE, Brazil) ${ }^{24}, 84 \%$ answered that they did not know about the risk factors for cancer or gave answers like inflammation, venereal disease or poor hygiene. In a study in Pakistan ${ }^{25}$, 
$1.8 \%$ of the women did not know cervical cancer was a disease, and only $26 \%$ were aware of one or more risk factors.

$57 \%$ of the women reported the main form of prevention is the Papanicolaou test, and $11.8 \%$ mentioned hygiene. In the city of Juiz de For a (MG), participants affirmed that the main preventive measures are taking regular Papanicolaou tests $(72 \%)$ and using condoms $(8 \%)^{26}$. A worrisome finding in the study is that $35.4 \%$ of the women do not know about any preventive measure. In Propriá (SE, Brazil), $77 \%$ of the studied women do not know how to protect themselves and only $23 \%$ had some idea about it, like the use of condoms $(4 \%)^{24}$. The lack of knowledge about the risk factors and prevention methods may be related to the lack of information given by health professionals, poor access to efficient female educational programs and mass screening.

We could observe in the research that the adequate knowledge and practice have statistically significant association with women who had seven or more years of schooling and the ones whose family income is equal or higher than three times the minimum wage. Previous studies showed similar results in which income and schooling are directly related to appropriate practice ${ }^{3,27}$ and appropriate knowledge about the Papanicolaou test as a prevention form $3,6,27$.

The statistically significant association among educational level, knowledge and attitudes probably happen due to the women's a greater awareness about the advantages and benefits of periodic examination and better access to information and health services.

The fact that there is an association between their age and the practice of tests is also important to notice. In Guarapuava and in the state of Rio Grande do Sul, the association of the women's age and the preventive examinations of cervical cancer was also statistically significant - we could see that there is higher participation of women aged between 25 and $40^{16,28}$. A possible explanation for this association between age and the adequate practice may be due to the fact that women in reproductive age take the tests because they are part of the routine procedures for prenatal care, or part of family planning 29,30. However, in other Latin American countries, such as Argentina and Peru, we could not find associations between age and test practice ${ }^{11,31}$.

One of the study's limitations was the method used to estimate the practice of Papanicolaou test. Data collection on the proper practice was made from the women's own reports about their tests history. Questions about the exam assume some previous knowledge about it. Besides that, women tend to overestimate the frequency of tests and underestimate the time when the last preventive examination happened ${ }^{32}$.

Several researches, however, have used the data related to clinical breast examination and mammography, whilst some studies in the United States of America have found high correlation between the reported data and the data registered in medical records. This information confirms the interview is a reliable and less expensive method of data collection ${ }^{33,34}$. The cross-sectional design of the study is also another limitation for the possibility of interpreting the cause-effect associations that were found.

The results show that significantly higher proportions of adequate knowledge were identified among women who had seven years of schooling or more, and those whose family income was three times the minimum wage or more. Significant associations for the adequate practice were found among women aged 39 or less, who had seven years of schooling or more, and who reported a family income of three times the minimum wage or more.

From this, it is important to redesign the primary care strategies to attract older women, with low schooling and low socioeconomic conditions, for them to know the main risk factors of CC and take periodical tests. The data from this study and from others that may follow it - may be relevant contributions to improve the understanding of links among the variables and offer useful elements for the implementation of measures aimed at the maintenance, improvement and promotion of physical well-being of people.

\section{REFERENCES}

1. Instituto Nacional de Câncer (Brasil). Estimativa 2010. Incidência do Câncer no Brasil. Rio de Janeiro: INCA, 2009.

2. Leite MLJGT, Tanaka ACA. Analysis of the tendencies over time of mortality due to uterine cancer in the state of São Paulo: 1980 to 1998. Rev Bras Crescimento Desenvolv Hum. 2007;17(1):95-103.

3. Brasil, Ministério da Saúde, Secretaria Nacional de Assistência à Saúde, Instituto Nacional do Câncer, Coordenação de programas de controle do câncer. Estimativas da incidência e mortalidade por câncer no Brasil-2000. Rio de Janeiro: INCA; 2008

4. Oliveira MM, Pinto IC. Percepção das usuárias sobre as ações de prevenção do câncer do colo

do útero na estratégia saúde da família em distrital de saúde do município de Ribeirão Preto, São Paulo, Brasil. Rev. Bras. Saúde Mater. Infant. 2007 jan./mar.;7(1):31-8.

5. Ferreira MLM, Oliveira C. Conhecimento e significado para funcionárias de indústrias têxteis sobre prevenção do câncer do colouterino e detecção precoce do câncer da mama. Revista Brasileira de Cancerologia 2006; 52(1): 5-15.

6. Brasil. Ministério da saúde. Instituto nacional do câncer. Controle do câncer cérvico-uterino e de mama. Rio de Janeiro: Ministério da Saúde; 2006.

7. Barros DM, Batista SMS, Siqueira RCR. Analisando a gestão municipal na prevenção do câncer do colo do útero: o caso Quissamã [Internet]. Rio de Janeiro. Rio de 
9. Toriy AM, Krawulski E, Viera JSB, Luz CM, Sperandio FF. Perceptions, feelings and physical and emotional experiences of woman after breast cancer. Journal of Human Growth and Development 2013, 23(3): 303-308.

10. Instituto Brasileiro de Geografia e Estatística. [Internet]. Bauru:[editora desconhecida]; 2010 [citado 2012 Out 20]. IBGE Cidades@. Disponível em: http://www.ibge.gov.br/ cidadesat/topwindow.htm.

11. Brasil, Ministério da Saúde. [Internet] Incidência de câncer no Brasil: estimativa/ 2005. Brasília: Instituto Nacional do Câncer; 2004. [citado 2011 Jan 30] Disponível em: http://www.inca.gov. br/estimativa2005.

12. Pinho AA. Fatores Associados à Realização do Teste Papanicolaou entre Mulheres em Idade Reprodutiva no Município de São Paulo. [Dissertação]. São Paulo: Universidade de São Paulo; 2002. 225f.

13. Norman GR, Streiner DL. Biostatitics: The base essentials. St. Lowis: Mosby-Year Book, 1994

14. Nascimento CM, Eluf-Neto J, Rego RA. Cobertura do teste de Papanicoloau no município de São Paulo e características das mulheres que realizaram o teste. Bol. Oficina Sanit Panam. 1996; 121(6):491-9.

15. Bim CR, Pelloso SM, Carvalho MDB, TIS Previdelli. Diagnóstico precoce do câncer de mama e colo uterino em mulheres do município de Guarapuava, PR, Brasil. Rev Esc Enferm USP. 2010; 44(4):940-6.

16. Silva DW, Andrade SM, Soares DA, Turini B, Schneck CA, Lopes MLS. Cobertura e fatores associados com a realização do exame Papanicolaou em município do Sul do Brasil. Rev Bras Ginecol Obstet. 2006; 28(1): 24-31.

17. Fernandes JV, Rodrigues SHL, Costa YGAS, Silva LCM, Brito AML, Azevedo JWV, Nascimento ED, Azevedo PRM, Fernandes TAAM. Conhecimentos, atitudes e prática do exame de Papanicolaou por mulheres, Nordeste do Brasil. Rev Saúde Pública 2009;43(5):851-8.

18. De Oliveira MMHN, Da Silva AAM, Brito LMO, Coimbra LC. Cobertura e fatores associados à não realização do exame de Papanicolaou em São Luis, Maranhão. Rev Bras Epidemiol. 2006;9(3):325-34.

19. Amorim VMSL, Barros MBA, César CLG, Carandina L, Goldbaum M. Fatores associados a não realização do exame de Papanicolaou: um estudo de base populacional no Município de Campinas, São Paulo, Brasil. Cad Saude Publica. 2006; 22(11):2329-38.

20. Floriano MI, Araújo CSA, Ribeiro MA. Conhecimento sobre fatores de risco associados ao câncer do colo uterino em idosas em Umuarama-PR. Arq. Ciênc. Saúde Unipar. 2007; 11(3):199-03.

21. Gamarra CJ, Paz EPA, Griep RH. Conhecimentos, atitudes e a prática do exame de Papanicolaou entre mulheres argentinas. Rev Saúde Pública. 2005; 39(2), 270-276.
22. Urrutia MTS, Poupin LB, Concha XP, Viñales DA, Iglesias CN, Reyes VI. Por Qué Las Mujeres No Se Toman El Papanicolau?: Barreras Percibidas Por Un Grupo De Mujeres Ingre-sadas Al Programa De Cáncer Cervicouterino Auge*. Rev Chil Obstet Ginecol. 2008; 73(2), 98-103.

23. Huamani C, Hurtado-Ortega A, Guardia-Ricra M, Roca-Mendoza J. Conocimientos y actitudes sobre la toma de Papanicolaou en mujeres de Lima, Perú, 2007. Rev Peru Med Exp Salud Publica. 2008; 25(1):44-50.

24. Lima CA, Palmeira JAV, Cipolotti R. Fatores associados ao câncer do colo uterino em Propriá, Sergipe, Brasil. Cad. Saúde Pública. 2006; 22(10):2151-56.

25. Ali SF, Ayub S, Manzoor1NF, Azim S, Afif M, Akhtar N, Jafery WA, Tahir I, Farid-ul-Hasnian S, Uddin N. Knowledge and Awareness about Cervical Cancer and Its Prevention amongst Interns and Nursing Staff in Tertiary Care Hospitals in Karachi, Pakistan. PLoS One. 2010; 5(6): e11059.

26. Santos MS, Macêdo APN, Leite MAG. Percepção de Usuárias de uma Unidade de Saúde da Família Acerca da Prevenção do Câncer do Colo do Útero. Rev. APS. 2010; 13(3):310-319.

27. Freitas RAP, Carvasan GAF, Morais SS, Zeferino LC. Prevalência das lesões neoplásicas do colo de útero resultados de rastreamento citológico realizado em Campinas, São Paulo, Brasil. Rev. Ciênc. Med. 2006; 12(4):307-14.

28. Gonçalves CV, Duarte G, Costa JSD, Quintana SM, Marcolin AC. Perdas de oportunidades na prevenção do câncer de colo uterino durante o pré-natal. Ciênc. saúde coletiva. 2011, 16(5): 2501-2510.

29. Klimousky E, Matos E. El uso de la prueba de papanicolaou por una población de Buenos Aires. Bol Oficina Sanit Panam 1996;121(6):502-9.

30. Robles S, White F, Peruga A. Tendencias de la mortalidad por cáncer del cuello de útero en las Américas. Bol Oficina Sanit Panam 1996;121(6):478-90.

31. Bazán F, Posso M, Gutiérrez C. Conocimientos, actitudes y prácticas sobre la prueba de Papanicolau. An Fac Med Lima. 2007; 68(1).

32. Freitas RAP, Carvasan GAF, Morais SS, Zeferino LC. Prevalência das lesões neoplásicas do colo de útero resultados de rastreamento citológico realizado em Campinas, São Paulo, Brasil. Rev. Ciênc. Med. 2006; 12(4):307-14.

33. Montano DE, Phillips WR. Cancer screening by primary care physicians: a comparison of rates obtained from physician self-report, patient survey, and chart audit. Am J Public Health. 1995; 85: 795-800.

34. Caplan LS, McQueen DV, Qualters ML, Garret C, Calonge N. Validity of women's self-reports of cancer screening test utilization in a managed care population. Cancer Epidemiol Biomark Prev. 2003; 12:1182-7. 